\title{
Effects of electron beam irradiation on the quality of star apple fruits (Chrysophyllum cainito)
}

Ly Thi Nguyen ${ }^{1}$

http://orcid.org/0000-0003-1631-9916

Thi The Doan 1

http://orcid.org/0000-0002-0148-0953

Van Chung Cao ${ }^{1}$

http://orcid.org/0000-0003-2140-4066

Thu Hong Thi Pham ${ }^{1}$

http://orcid.org/0000-0001-5251-2751

Thanh Duoc Nguyen ${ }^{1}$

http://orcid.org/0000-0001-9283-5248

\section{Son Khanh Trinh ${ }^{2, *}$}

http://orcid.org/0000-0002-6365-2693

${ }^{1}$ Research and Development Center for Radiation Technology, Vietnam Atomic Energy Institute 202A

Street 11, Linh Xuan Ward, Thu Duc District, Ho Chi Minh City, Vietnam;

${ }^{2}$ Ho Chi Minh City University of Technology and Education, 1 Vo Van Ngan street, Linh Chieu Ward,

Thu Duc District, Ho Chi Minh City, Vietnam;

*Correspondence: sontk@hcmute.edu.vn

Received: 2019.07.20; Revised: 2019.10.25; Accepted: 2019.11.01; Published: 2020.01.01

Highlights: The paper addresses the "quality control of Vietnam star apple fruits using electron beam irradiation" and is important because "this study using a physical and eco-friendly treatment, which can be applied in practical treatment."

Section: This paper was submitted in Food technology, a section of the J. Bioen Food Sci.

Competing interests: There is not conflict of interest in the research conducted.

Funding: The work was supported by Grant CS/17/07-02 from the Vietnam Atomic Energy Institute (VINATOM). And this research is also a part supported by International Atomic Energy Agency (IAEA) under Research Contract no. 18984.

Citation as (APA): Nguyen, L.T., Doan, T.T., Cao, V.C., Pham, T.H.T., Nguyen, T.D. \& Trinh, S.K. (2020). Effects of electron beam irradiation on the quality of star apple fruits (Chrysophyllum cainito). Journal of bioenergy and food science, 7(1), e2762019JBFS. doi: 10.18067/jbfs.v7i1.276

Edited by Dr. Victor Hugo Gomes Sales - Federal Institute of Amapá, Macapá-AP, Brazil.

Review processes: 2762019R01 | 2762019R02 
ABSTRACT - Irradiated star apples at the minimum absorbed dose of 400 Gy for phytosanitary purpose in Vietnam have been already approved to import to US. In this study, the fresh star apples were treated with electron beams at doses of $0.4,0.6,0.8$ and $1.0 \mathrm{kGy}$ to evaluate its effect on quality of fruits. The results showed that electron beam radiation doses of $0.4 \mathrm{kGy}$ and $0.6 \mathrm{kGy}$ did not affect to the surface color and percentage of weight loss of fruits. There was significant difference in overall acceptability score with the values of 3.95, 3.92 and 2.45 between irradiated fruits at 0.4, $0.6 \mathrm{kGy}$ and the control (0 kGy) respectively after 6 days in storage at the ambient conditions (temperature of $26 \pm 10 \mathrm{C}$ and humidity of $85-90 \%$ ). Thus, dose range between 0.4 and $0.6 \mathrm{kGy}$ should be used to extend the shelf life of star apple fruits. Because of the low penetration depth of electron beams onto products, dose uniformity ratio (DUR) in the standard carton box for packaging the star apple fruits as well as absorbed doses outside and inside of fruits were calculated.

Keywords: Electron beam; Irradiation; Star apple fruits; Quality; Dose uniformity ratio

\section{INTRODUCTION}

Star apple (Chrysophyllum cainito) is a member of the family Sapotaceae. In Vietnam, it is called "Vú Sữa" (literally: milky breast). The most famous variety is "Lò Rèn" star apple growing in Vinh Kim commune, Chau Thanh district, Tien Giang province. It becomes one of important fruits for exportation. The fruit is non-climacteric and an excellent source of vitamins and irons when ripen (Yahia \& Orozco, 2011). The fruit characteristics are round shape, light yellow color and light green color, mild sweet flavor and good smelling and the pulp is white or creamy white, with numerous tiny black seeds (Fruit Vietnam, 2015). The harvest time of star apple fruits is limited from December to March, and their quality become worse in a period of 5 days after harvest at ambient temperature with the deterioration starting to change of color and followed by shrinking of the fruit (Le, 2016; Amusa, Ashaye, \& Oladapo, 2003).

The star apple fruits from Vietnam have been approved to be imported to US since July 2017 by USDA/APHIS. However, The US maintains strict quarantine measures against some pests. According to the request, the fruit from Vietnam must be irradiated at minimum absorbed dose of 400 Gy by gamma rays, electron beam (EB) or X-ray (APHIS, 2016). In EB irradiation, the penetration depth depends on the areal density range of the product, and can be estimated by the package dimensions and the product density. The dose uniformity ratio (DUR) was calculated by the maximum dose and the minimum required dose. Follett et al. (2007) reported that DUR value at the commercial electron beam facility designed to treat fresh products is typically from 1.5 to 2.0. Therefore, commodities treated with radiation receive maximum doses from 600 to 800 Gy and fresh fruits can be irradiated at dose up to 1 kGy (Follett, Yang, Lu, \& Chen, 2007; IFST, 2015). In addition, previous papers reported that irradiation can extend the postharvest life of many tropical and subtropical fruits by preventing growth of the microorganisms that cause food deterioration. For example, mango treated at dose of $0.45 \mathrm{kGy}$ by gamma ray to reduce the development of pathogen without damage of nutrient (Dionísio, Gomes, \& Oetterer, 2009; Santos, Lin, da Silva, \& de Oliveira, 2015). Gamma ray irradiation at dose of $0.2 \mathrm{kGy}$ can extend the shelf life of guava (Sau, Datta, Sarkar, \& Sarkar, 2018). The combination of sodium-dichloroisocyanurate (NaDCC) and gamma radiation can be applied to preserve postharvest paprika (Yoonet al., 2014). For custard apple,the dose of $1.5 \mathrm{kGy}$ combined with50 ppm benzyl adenine enhanced fruits shelf- life by 6 days in storage at ambient temperature with good pulp texture, flavor, color and nutritional quality compared to control (Chouksey, Singh, Thakur, \& Deshmukh, 2013).

To the best of our knowledge, there has been not any report about phytosanitary for star apples as well as their radio-tolerance by EB irradiation. In addition, effects of EB on the quality of fruits have not been mentioned yet. Usually the fruits are packaged in a variety of shapes and sizes. Therefore, it is necessary to perform dose-mapping studies for representative irradiation. In this study, the effect of EB irradiation on the quality and the DUR value of star apple fruits were evaluated. 


\section{MATERIAL AND METHODS}

\section{a) Sample preparation}

Lò Rèn star apple fruits were harvested from 240 to 250 day after flowering. The mainharvest fruit were readily available from commercial orchards meeting Global GAP standard in Vinh Kim commune, Chau Thanh district, Tien Giang province. The fruits harvested in the afternoon and immediately transported to laboratory at the Research and Development Center for Radiation Technology (VINAGAMMA), Ho Chi Minh City, Vietnam in the next early morning. After washing and trimming of remainder stems, the standard fruits (weight from 250 to 300 gram / fruit and diameter from 5 to $7 \mathrm{~cm}$ ) without spots were assigned randomly for treatment.

\section{b) Irradiation of star apple fruits}

Electron beam (EB) irradiation was conducted at the Research and Development Center for Radiation Technology (VINAGAMMA Center in Ho Chi Minh City, Vietnam). The $10 \mathrm{MeV}$ and 15 kW linear accelerator (UERL-10-15S2, Corad Services Ltd, Russia) with two beams (top and bottom) was used in this study. Star apple fruit samples were treated with target absorbed doses of $0.4,0.6,0.8$ and $1.0 \mathrm{kGy}$ within 1 hour after prepared. The EB machine was set to deliver a constant dose of $0.4 \mathrm{kGy}$ by running the conveyor belt at $2.7 \mathrm{~m} / \mathrm{min}$. The room temperature was around $26 \pm 1^{\circ} \mathrm{C}$. For the doses higher than $0.4 \mathrm{kGy}$, the conveyor belt speed was appropriately changed slower than at dose of $0.4 \mathrm{kGy}$. For each dose, irradiation was repeated at least three times. After irradiation, fruits were stored at ambient conditions (temperature of $26 \pm 1{ }^{\circ} \mathrm{C}$ and humidity of $85-90 \%$ ) to determine color, Brix degree, vitamin $\mathrm{C}, \mathrm{pH}$, weight loss, decay percentage and to evaluate sensory in duration of storage. Un-irradiated sample is as the control. For each treatment, 27 fruits were used for three replications.

\section{c) Color measurement}

The surface color of star apple was measures using Minolta Chroma Meter (ModelCR400, Konica Minolta Co., Japan) chromameter in $L^{*} a^{*} b^{*}$ system and illuminant $D_{65}, 2^{\circ}$ standard white standard tile. In this system, $L^{*}$ represents lightness (high values) and darkness (low values), $+a^{*}$ redness, $-a^{*}$ greenness, and $+b^{*}$ yellowness, $-b^{*}$ blueness (Eissa \& Zohair, 2006; Zalewska, Marcinkowska-Lesiak \& Onopiuk, 2017). Measurements were taken on 3 different points of each fruit, and the mean value was calculated.

\section{d) Fresh weight loss and decay rate measurements}

Weight loss (WL) for each treatment was determined by monitoring the fresh weight change during the storage period and calculated the WL as in equation (1) (Singh, Singh \& Singh, 2006):

$$
W L(\%)=((\text { Fresh weight }- \text { Weight at storage interval }) /(\text { Fresh weigth })) \times 100
$$

\section{e) Decaymeasurement}

Any fruit showing sign of soft rot, a brown spot or mould was considered as decayed. Decay percentage was calculated as Equation (2) (Singh, Singh, \& Singh, 2006):

Decay percentage $(\%)=(($ Number of decayed fruit $) /($ Total of tested fruits $)) \times 100$

Eq. (2) 


\section{f) $\mathrm{pH}$ measurement}

Flesh of star apple fruits was previously homogenized with a grinder and were filtered by filter paper then, a pH of the solution was measured using a digital $\mathrm{pH}$ meter (Hanna Instruments, Inc, USA). An average of three replicates of each solution of homogenized star apple fruits from each dose was evaluated.

\section{g) Soluble solid ( ${ }^{\circ}$ Brix) and ascorbic acid content}

The total soluble solid (TSS) content was determined with a handheld refractometer (TIRBX32, Trans Instruments Pte Ltd., Singapore). The readings for TSS were expressed as ${ }^{\circ}$ Brix. Flesh of the fruit was crushed and homogenized and then $1 \mathrm{ml}$ of the homogenates was measured. 2005a).

Ascorbic acid content was determined according to the method of AOAC 67.21 (AOAC,

\section{h) Sensory testing}

Sensory testing was performed by 10 members including students and staff at VINAGAMMA center and numerical values were assigned to each attribute on a 5-point scale where, $1=$ very poor, 2 = poor, $3=$ fair, $4=$ good and 5 = excellent) (Dawson \& Harris, 1951). Scores from 2.5 to 5 were considered acceptable (Abu-Tarboush et al., 1997). The sensory analysis was performed at $0,3,6,9$, and 12 days after irradiation.

\section{i) Evaluation of dose uniformity ratio (DUR)}

A single layer of star apple and five Fricke dosimeters were placed at surface each box with size of $49 \mathrm{~cm}(\mathrm{~L}) \times 32 \mathrm{~cm}(\mathrm{~W}) \times 12 \mathrm{~cm}(\mathrm{H})$ and with gross weight of around $4 \mathrm{~kg}$ in the areas where maximum and minimum absorbed doses were measured (Fig.1a). To determine the dose distribution inside and outside the star apple fruits, B3 films (supplied by GEX Corp., USA) were used and places different places as described in Fig. 1 ( $b$ and $c$ ) then irradiated at estimated dose of $0.4 \mathrm{kGy}$. After irradiation, the dosimeters were measured to calculate the dose variation within each carton box and the fruit. Each experiment was repeated three times.

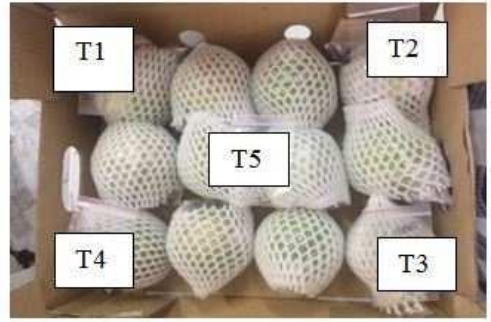

(a)

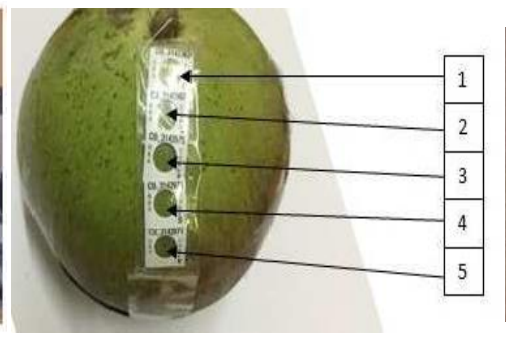

(b)

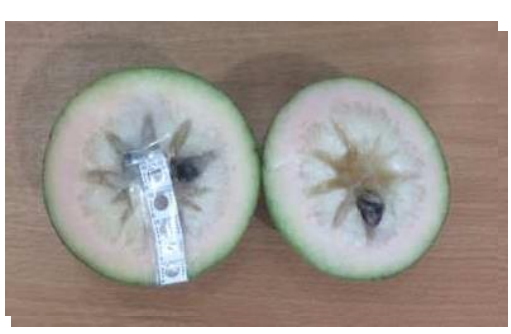

(c)

Figure 1 Dosimeters places in the carton box (a), outside (b) and inside (c) of a Lò Rèn star apple fruit

\section{j) Statistical analysis}

Data were subjected to analysis of variance (ANOVA) at $P<0.05$ using SPSS 13.0 software and Duncan's multiple range tests were used to compare the differences among the mean values. 


\section{RESULTS AND DISCUSSION}

\section{a) Effect of electron beam irradiation on chemical composition of star apple fruits during storage time}

The Figure $2 a$ indicated that the total soluble solid (TSS) decreased with increasing storage time. TSS at 0 day was of $12,11.9,11.9,12.9$ and $12.3^{\circ}$ Brix for samples treated at dose of 0 , $0.4,0.6,0.8$ and $1.0 \mathrm{kGy}$, respectively. After 12 days, the value was reduced to $9.2,8.8,8.3,9.3$ and $9.2^{\circ}$ Brix, respectively. The result can be explained that the star apple is a non-climacteric fruit so it must mature on the tree before being harvested. At the time of mature, the TSS content of the fruit reaches to the greatest value. After harvesting, the TSS does not increase any more. In addition, the respiration of the fruits continues after harvest. However, there was insignificant difference among control sample and irradiated samples at the same storage time. Similarly, Wall \& Khan (2008) reported that TSS of dragon fruits was not affected by absorbed dose up to $0.8 \mathrm{kGy}$. Ascorbic acid content and $\mathrm{pH}$ value were presented in Figure $2 \mathrm{~b}$ and $2 \mathrm{c}$. After $6 \mathrm{~d}$ storage at ambient temperature, the $\mathrm{pH}$ value in irradiated samples was lower than the control sample and was significant difference compared with the control (un-irradiated sample). At the end of storage time, the $\mathrm{pH}$ value in irradiated samples was not significant difference in comparison with the control sample.

Ascorbic acid content decreased with the increase of dose and storage time but it was not significant difference among all samples at the same time. The result was similar with the results of Zaman, Paul, Alam, Ibrahim, \& Hassan (2007) reported that ascorbic acid content of irradiated bananas at dose lower than one kGy was not significant difference among all samples. Zhang, Deng, Fu, \& Weng (2014) reported the same results on ascorbic acid content of Shatang mandarin that was not significant difference among treated groups and the control until $30 \mathrm{~d}$ at $4{ }^{\circ} \mathrm{C}$ after using gamma irradiation and refrigerated storage. Ascorbic acid content in guava exposed to 0.25 kGy was not significant difference with the control (Singh \& Pal, 2009).
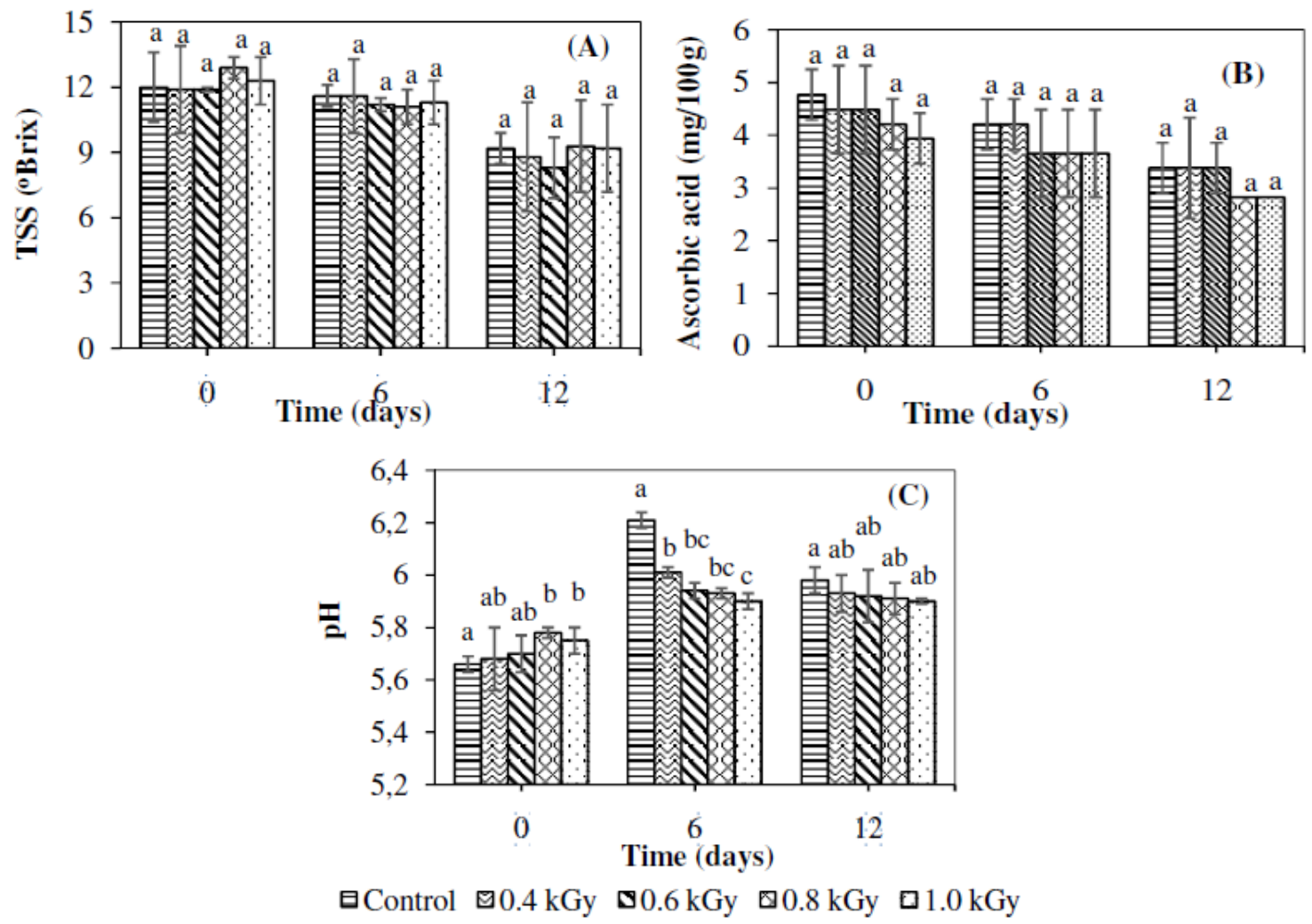

Figure 2 Effects of EB irradiation on (A) the soluble solids ( ${ }^{\circ}$ Brix); (B) Ascorbic acid; and (C) pH during storage time (Temperature of $27 \pm 2{ }^{\circ} \mathrm{C}$; $\mathrm{RH}: 85 \pm 5 \%$ ).

The values followed by the different letters are significantly different $(P<0.05)$ by Duncan's multiple range test. 


\section{b) Effect of electron beam irradiation on weight loss and decay rate of star apple fruits during storage time}

Weight loss of star apple was observed during experimental process (Figure 3A). All samples were stored at ambient temperature $\left(26 \pm 1^{\circ} \mathrm{C}\right)$ and observed every 3 days. The weight loss (\%) increased significantly with the increase of storage time. There was insignificant difference among irradiated samples and the control in weight loss during first 3-day of storage time. After 3 days, weight loss in all samples fastly increased, especially for samples treated at dose of $\geq 0.8$ kGy. However, weight loss of star apple insignificantly changed for $\leq 0.6 \mathrm{kGy}$ treated samples. Actually, there were not so much published evidences of irradiation effects on quality of star apple fruit. These results above indicated that the irradiation treatment with dose range from 0.8 to $1.0 \mathrm{kGy}$ caused damage to the star apple fruits. Zhang, Deng, Fu \& Weng (2014) reported the effect of gamma irradiation on Shatang mandarin. Weight loss of irradiated Shatang mandarin at lower dose (0.2-0.4 kGy) was lower than that of higher dose ( $\geq 0.5 \mathrm{kGy})$. Futhermore, weight loss of dragon fruits treated at dose of 0.6 or $0.8 \mathrm{kGy}$ was higher than that of the control after 12 days at $10^{\circ} \mathrm{C}$ (Wall \& Khan, 2008). Rezaee, Almassi, Minaei \& Paknejad (2013) explained that a change in the membrane function of the irradiated samples which increased in permeability causing higher respiration.

No significant decay was recorded in all samples up to 3 days of ambient storage. The decay rate was less than $50 \%$ for irradiated samples as compared to more than $50 \%$ in control sample especially at dose of $0.8 \mathrm{kGy}$ and $1.0 \mathrm{kGy}$ had the least decay rate of $13 \%$ after 6 days at ambient condition. The decay rates reached $100 \%$ after 9 days irradiation in all treatments (Figure 3b). Similarly, strawberry was treated by gamma irradiation (Rabab and Khaled, 2016). Irradiated strawberry was slower down decay than the control sample especially at a dose of 0.6 and $0.9 \mathrm{kGy}$. Because on this dose can be inhibiting microbial proliferation. However, other non-climacteric fruits, such as dragon fruits, the fruit decay was not affected by X-ray irradiation up to dose of $0.8 \mathrm{kGy}$ (Wall and Khan, 2008). While, Shatang mandarin treated by gamma ray at 0.5 and 0.6 kGy had decay rates higher than the decay rates of 0.2-0.4 kGy irradiated group (Zhang, Deng, Fu \& Weng, 2014). The results can be explained that the decay rate depend on type of irradiation and type of fruits.
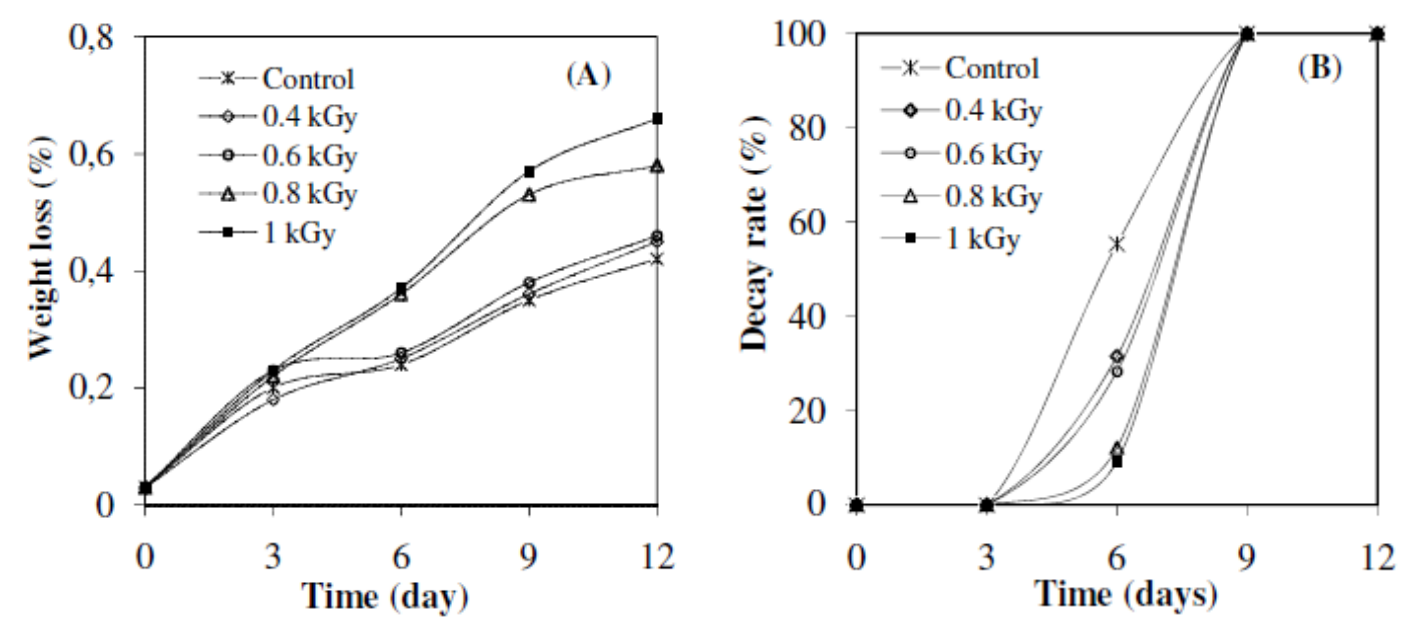

Figure 3 Effect of EB radiation on weight loss $(A)$ and decay rate of star apple fruits $(B)$ during storage at ambient condition (Temperature of $26 \pm 2{ }^{\circ} \mathrm{C} ; \mathrm{RH}: 85-90 \%$ ).

\section{c) Effect of electron beam irradiation on color of star apple fruits during storage time}

The color of fruits is a very important characteristic for acceptance from consumer and the most evident indicator of their quality (Pathare, Opara \& Al-Said., 2012; Drake \& Neven, 1997). Changes in the external color were monitored by measuring lightness $\left(L^{*}\right)$, redness $\left(a^{*}\right)$, and yellowness $\left(b^{*}\right)$ (Table 1 and Figure4). Irradiation affected the lightness ( $L^{*}$ values) of star 
apple exposed to 0.8 and $1.0 \mathrm{kGy}$ as they became lighter (higher values than the control) after irradiation (day 6). However, exposed to $0.6 \mathrm{kGy}$ was not affect the lightness of the samples on that day. The changes in $L^{*}$ values with the dose was reported by Drake and Neven (1997) in irradiated Bing'cherries. Following the report $L^{*}$ values increased at irradiation doses greater than 0.15 kGy. Moreno, Perez, Gomes, Da Silva, \& Moreira, (2006) reported similar result in mango. By the end of storage, the samples exposed to $0.8 \mathrm{kGy}$ and $1.0 \mathrm{kGy}$ showed darker than the others show but was not significant different. These results could be attributed to an increased polyphenoloxidase activity and the consequent oxidation of phenolics giving rise to brown and dark pigmentation of the fruit (Thomas, 1986). The redness (a values) of the samples exposed to $0.8 \mathrm{kGy}$ and $1.0 \mathrm{kGy}$ was significantly $(\mathrm{P}>0.05)$ higher (more red) than the sample exposed to 0.6 kGy after 6 days storage. Similar results were observed for $b^{*}$ value (the yellowness) in Table 1. Discoloration of the star apple could be attributed to the water loss in the fruits. Moreno, Perez, Gomes, da Silva,\& Moreira (2007) reported the same result for blueberries irradiated with EB at dose of $1.1 \mathrm{kGy}$.

Table 1 Effect of EB irradiation on surface color of star apple during storage time under ambient condition (temperature of $26 \pm 1^{\circ} \mathrm{C}$ and humidity of $85-90 \%$ ).

\begin{tabular}{ccccccc}
\hline \multirow{2}{*}{ Parameter } & \multirow{2}{*}{ Sample } & \multicolumn{5}{c}{ Surface color } \\
\cline { 2 - 7 } & & $0 \mathrm{~d}$ & $3 \mathrm{~d}$ & $6 \mathrm{~d}$ & $9 \mathrm{~d}$ & $12 \mathrm{~d}$ \\
\hline \multirow{4}{*}{$\mathrm{L}^{*}$} & Control & $62.04^{\mathrm{a}} \pm 1.14$ & $60.55^{\mathrm{a}} \pm 1.31$ & $57.54^{\mathrm{a}} \pm 1.08$ & $56.05^{\mathrm{a}} \pm 4.15$ & $43.54^{\mathrm{a}} \pm 6.96$ \\
& $0.4 \mathrm{kGy}$ & $58.95^{\mathrm{a}} \pm 1.35$ & $60.71^{\mathrm{a}} \pm 0.81$ & $57.90^{\mathrm{a}} \pm 0.72$ & $57.24^{\mathrm{a}} \pm 5.72$ & $38.45^{\mathrm{a}} 8.43$ \\
& $0.6 \mathrm{kGy}$ & $61.61^{\mathrm{a}} \pm 0.81$ & $61.64^{\mathrm{a}} \pm 1.01$ & $56.74^{\mathrm{a}} \pm 0.53$ & $53.63^{\mathrm{a}} \pm 2.16$ & $40.06^{\mathrm{a}} \pm 5.57$ \\
& $0.8 \mathrm{kGy}$ & $63.37^{\mathrm{a}} \pm 5.14$ & $60.97^{\mathrm{ab}} \pm 0.72$ & $60.31^{\mathrm{b}} \pm 2.11$ & $51.18^{\mathrm{a}} \pm 2.87$ & $39.99^{\mathrm{a}} \pm 0.79$ \\
& $1.0 \mathrm{kGy}$ & $63.14^{\mathrm{a}} \pm 6.86$ & $63.16^{\mathrm{b}} \pm 0.98$ & $60.92^{\mathrm{b}} \pm 1.06$ & $49.47^{\mathrm{a}} \pm 4.76$ & $38.88^{\mathrm{a}} \pm 0.91$ \\
\hline \multirow{4}{*}{$\mathrm{a}^{*}$} & Control & $-13.65^{\mathrm{a}} \pm 1.37$ & $-11.67^{\mathrm{a}} \pm 0.99$ & $-5.39^{\mathrm{a}} \pm 1.21$ & $-0.31^{\mathrm{a}} \pm 3.35$ & $3.56^{\mathrm{a}} \pm 0.30$ \\
& $0.4 \mathrm{kGy}$ & $-12.61^{\mathrm{ab}} \pm 1.03$ & $-11.17^{\mathrm{ab}} \pm 0.65$ & $-5.00^{\mathrm{ab}} \pm 2.76$ & $-0.14^{\mathrm{a}} \pm 3.05$ & $3.61^{\mathrm{a}} \pm 0.42$ \\
& $0.6 \mathrm{kGy}$ & $-11.77^{\mathrm{a}} \pm 2.20$ & $-10.25^{\mathrm{ab}} \pm 0.42$ & $-5.99^{\mathrm{a}} \pm 4.45$ & $-0.68^{\mathrm{a}} \pm 3.55$ & $4.80^{\mathrm{b}} \pm 1.01$ \\
& $0.8 \mathrm{kGy}$ & $-12.73^{\mathrm{a}} \pm 1.80$ & $-10.69^{\mathrm{ab}} \pm 0.88$ & $-3.56^{\mathrm{b}} \pm 3.48$ & $4.00^{\mathrm{b}} \pm 0.59$ & $4.80^{\mathrm{b}} \pm 0.78$ \\
& $1.0 \mathrm{kGy}$ & $-11.43^{\mathrm{a}} \pm 1.28$ & $-10.21^{\mathrm{b}} \pm 1.31$ & $-1.57^{\mathrm{a}} \pm 2.76$ & $3.45^{\mathrm{b}} \pm 0.60$ & $5.84^{\mathrm{b}} \pm 0.10$ \\
\hline \multirow{4}{*}{$\mathrm{b}^{*}$} & Control & $29.13^{\mathrm{a}} \pm 1.32$ & $29.08^{\mathrm{a}} \pm 0.63$ & $26.51^{\mathrm{a}} \pm 0.85$ & $22.56^{\mathrm{a}} \pm 1.21$ & $15.63^{\mathrm{a}} \pm 1.56$ \\
& $0.4 \mathrm{kGy}$ & $30.32^{\mathrm{ab}} \pm 1.27$ & $28.96^{\mathrm{a}} \pm 0.45$ & $27.42^{\mathrm{a}} \pm 0.33$ & $22.64^{\mathrm{a}} \pm 0.82$ & $16.81^{\mathrm{ab}} \pm 1.26$ \\
& $0.6 \mathrm{kGy}$ & $30.16^{\mathrm{ab}} \pm 1.09$ & $29.45^{\mathrm{ab}} \pm 0.26$ & $27.45^{\mathrm{a}} \pm 0.54$ & $24.77^{\mathrm{b}} \pm 0.19$ & $15.66^{\mathrm{a}} \pm 1.91$ \\
& $0.8 \mathrm{kGy}$ & $31.66^{\mathrm{b}} \pm 1.41$ & $30.24^{\mathrm{b}} \pm 0.51$ & $29.23^{\mathrm{b}} \pm 0.52$ & $25.99^{\mathrm{b}} \pm 1.41$ & $19.21^{\mathrm{b} \pm 1.50}$ \\
& $1.0 \mathrm{kGy}$ & $31.75^{\mathrm{b}} \pm 0.01$ & $31.56^{\mathrm{c}} \pm 0.21$ & $30.25^{\mathrm{b}} \pm 0.47$ & $26.17^{\mathrm{b}} \pm 0.16$ & $20.14 \mathrm{c} \pm 0.67$ \\
\hline
\end{tabular}

Control $=$ non-irradiated samples, Means values within a column having different letters are significantly different $(P<0.05)$

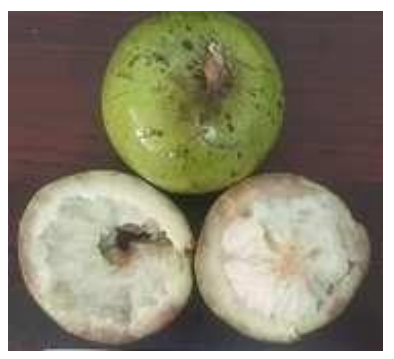

Control

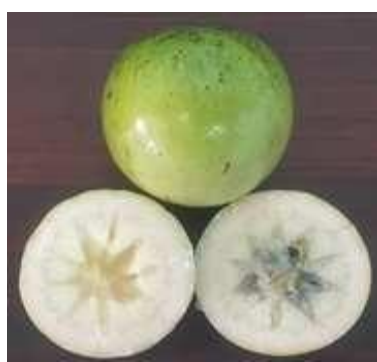

$0.4 \mathrm{kGy}$

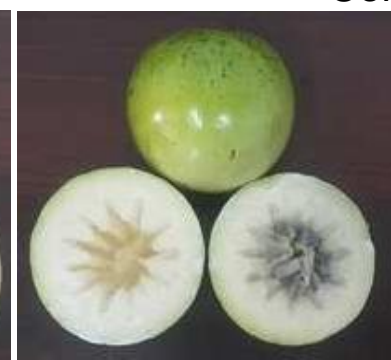

$0.6 \mathrm{kGy}$

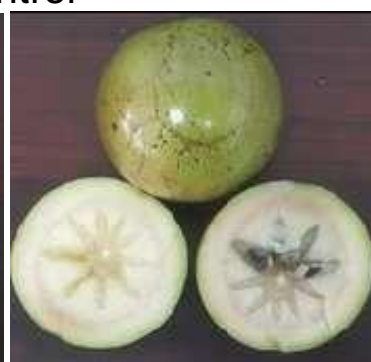

$0.8 \mathrm{kGy}$

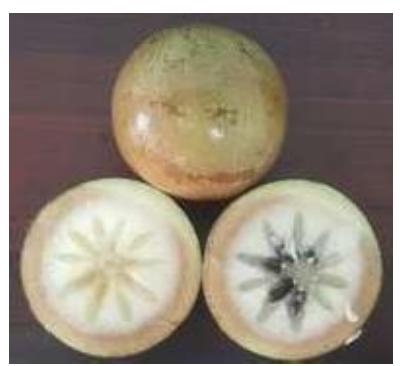

$1.0 \mathrm{kGy}$

Figure 4 Lò Rèn star apple fruits after 6 day stored at ambient condition (Temperature of

$\left.26 \pm 1^{\circ} \mathrm{C} ; \mathrm{RH}: 85-90 \%\right)$.

Journal of Bioenergy and Food Science. Vol.7: e2762019JBFS, 2020 


\section{d) Effect of electron beam irradiation on sensory assessment of star apple fruits during storage time}

Sensory evaluation of irradiated and un-irradiated samples was studied such as color, texture, taste and flavor of the star apple. The score during the survey of the star apple fruits affected by the dose and time was shown in Table 2. Table 2 shows that color is considered to be very good at day 0 (4.89). However, the gradual decrease in scores from 2.0 to 2.22 was observed in samples treated at doses of 0.8 to $1 \mathrm{kGy}$ at day 6 .

Table 2 Effect of EB irradiation on sensory parameter evolution of star apple fruits during storage time under ambient condition (27 $\left.\pm 2{ }^{\circ} \mathrm{C} ; \mathrm{RH}: 85-90 \%\right)$.

\begin{tabular}{|c|c|c|c|c|c|c|}
\hline Day & Sample & Color & Flavor & Texture & Taste & $\begin{array}{c}\text { Overall } \\
\text { acceptability }\end{array}$ \\
\hline \multirow{5}{*}{ Od } & Control & $4.89^{a} \pm 0.22$ & $4.94^{\mathrm{a}} \pm 0.17$ & $5.00^{\mathrm{a}} \pm 0.17$ & $5.00^{a} \pm 0.00$ & $4.96^{a} \pm 0.05$ \\
\hline & $0.4 \mathrm{kGy}$ & $4.94^{\mathrm{a}} \pm 0.17$ & $4.94^{\mathrm{a}} \pm 0.17$ & $4.94^{\mathrm{a}} \pm 0.17$ & $5.00^{\mathrm{a}} \pm 0.00$ & $4.96^{a} \pm 0.03$ \\
\hline & $0.6 \mathrm{kGy}$ & $4.94^{a} \pm 0.17$ & $4.94^{\mathrm{a}} \pm 0.17$ & $4.94^{\mathrm{a}} \pm 0.17$ & $5.00^{\mathrm{a}} \pm 0.00$ & $4.96^{a} \pm 0.03$ \\
\hline & $0.8 \mathrm{kGy}$ & $4.89^{a} \pm 0.22$ & $4.94^{a} \pm 0.22$ & $4.89^{a} \pm 0.22$ & $5.00^{\mathrm{a}} \pm 0.00$ & $4.93^{a} \pm 0.05$ \\
\hline & $1.0 \mathrm{kGy}$ & $4.89^{\mathrm{a}} \pm 0.22$ & $4.94^{\mathrm{a}} \pm 0.17$ & $4.94^{\mathrm{a}} \pm 0.17$ & $5.00^{\mathrm{a}} \pm 0.00$ & $4.94^{\mathrm{a}} \pm 0.04$ \\
\hline \multirow{5}{*}{$3 d$} & Control & $4.83^{a} \pm 0.25$ & $4.94^{a} \pm 0.17$ & $4.89^{a} \pm 0.22$ & $4.94^{a} \pm 0.17$ & $4.90^{\mathrm{a}} \pm 0.05$ \\
\hline & 0.4 kGy & $4.83^{a} \pm 0.25$ & $4.94^{\mathrm{a}} \pm 0.17$ & $4.89^{\mathrm{a}} \pm 0.22$ & $5.00^{\mathrm{a}} \pm 0.00$ & $4.92^{\mathrm{a}} \pm 0.07$ \\
\hline & $0.6 \mathrm{kGy}$ & $4.78^{a} \pm 0.36$ & $4.94^{\mathrm{a}} \pm 0.17$ & $4.83^{a} \pm 0.25$ & $5.00^{\mathrm{a}} \pm 0.00$ & $4.89^{a} \pm 0.10$ \\
\hline & $0.8 \mathrm{kGy}$ & $4.72^{a} \pm 0.36$ & $4.89^{a} \pm 0.22$ & $4.83^{\mathrm{a}} \pm 0.25$ & $5.00^{\mathrm{a}} \pm 0.00$ & $4.86^{\mathrm{a}} \pm 0.12$ \\
\hline & $1.0 \mathrm{kGy}$ & $4.72^{a} \pm 0.36$ & $4.89^{a} \pm 0.22$ & $4.83^{a} \pm 0.25$ & $5.00^{\mathrm{a}} \pm 0.00$ & $4.86^{a} \pm 0.12$ \\
\hline \multirow{5}{*}{$6 d$} & Control & $3.16^{\mathrm{b}} \pm 0.39$ & $2.89^{\mathrm{a}} \pm 0.22$ & $1.73^{\mathrm{a}} \pm 0.43$ & $2.01^{a} \pm 0.25$ & $2.45^{a} \pm 0.15$ \\
\hline & $0.4 \mathrm{kGy}$ & $3.72^{b c} \pm 0.36$ & $4.06^{c} \pm 0.46$ & $3.78^{b} \pm 0.36$ & $4.22^{\mathrm{c}} \pm 0.44$ & $3.95^{\mathrm{b}} \pm 0.24$ \\
\hline & $0.6 \mathrm{kGy}$ & $3.78^{b c} \pm 0.36$ & $4.06^{c} \pm 0.17$ & $3.72^{b} \pm 0.36$ & $4.11^{c} \pm 0.49$ & $3.92^{b} \pm 0.19$ \\
\hline & $0.8 \mathrm{kGy}$ & $2.22^{a} \pm 0.26$ & $3.65^{b c} \pm 0.25$ & $1.65^{a} \pm 0.43$ & $2.07^{b} \pm 0.35$ & $2.39^{a} \pm 0.23$ \\
\hline & $1.0 \mathrm{kGy}$ & $2.00^{\mathrm{a}} \pm 0.5$ & $3.39^{\mathrm{b}} \pm 0.65$ & $1.61^{\mathrm{a}} \pm 0.33$ & $2.05^{b} \pm 0.26$ & $2.26^{a} \pm 0.21$ \\
\hline \multirow{5}{*}{$9 d$} & Control & $1.89^{a} \pm 0.22$ & $1.33^{a} \pm 0.35$ & $1.33^{a} \pm 0.25$ & $1.56^{\mathrm{a}} \pm 0.46$ & $1.53^{a} \pm 0.26$ \\
\hline & 0.4 kGy & $2.17^{a} \pm 0.25$ & $1.72^{b} \pm 0.26$ & $1.56^{\mathrm{a}} \pm 0.3$ & $1.78^{a} \pm 0.26$ & $1.81^{\mathrm{ab}} \pm 0.26$ \\
\hline & $0.6 \mathrm{kGy}$ & $2.17^{a} \pm 0.95$ & $1.78^{\mathrm{b}} \pm 0.36$ & $1.56^{a} \pm 0.3$ & $1.67 a \pm 0.25$ & $1.79 \mathrm{ab} \pm 0.27$ \\
\hline & $0.8 \mathrm{kGy}$ & $1.33^{b} \pm 0.35$ & $1.67^{\mathrm{ab}} \pm 0.43$ & $1.56^{\mathrm{a}} \pm 0.17$ & $1.56^{\mathrm{a}} \pm 0.39$ & $1.53^{\mathrm{a}} \pm 0.14$ \\
\hline & $1.0 \mathrm{kGy}$ & $1.28^{b} \pm 0.51$ & $1.67^{\mathrm{ab}} \pm 0.5$ & $1.44^{\mathrm{a}} \pm 0.3$ & $1.56^{\mathrm{a}} \pm 0.3$ & $1.49^{a} \pm 0.17$ \\
\hline \multirow{5}{*}{$12 d$} & Control & $1.06^{\mathrm{a}} \pm 0.17$ & $0.78^{\mathrm{a}} \pm 0.26$ & $1.06^{\mathrm{a}} \pm 0.3$ & $0.94^{a} \pm 0.17$ & $0.96^{\mathrm{a}} \pm 0.13$ \\
\hline & 0.4 kGy & $1.11^{a} \pm 0.22$ & $0.89^{a} \pm 0.22$ & $1.22^{a} \pm 0.26$ & $1.00^{\mathrm{a}} \pm 0.25$ & $1.06^{a} \pm 0.14$ \\
\hline & $0.6 \mathrm{kGy}$ & $1.06^{\mathrm{a}} \pm 0.17$ & $1.00^{a} \pm 0.25$ & $1.22^{a} \pm 0.26$ & $0.94^{a} \pm 0.3$ & $1.06^{a} \pm 0.12$ \\
\hline & $0.8 \mathrm{kGy}$ & $0.94^{a} \pm 0.17$ & $0.83^{a} \pm 0.25$ & $1.22^{a} \pm 0.26$ & $1.06^{a} \pm 0.17$ & $1.01^{\mathrm{a}} \pm 0.17$ \\
\hline & $1.0 \mathrm{kGy}$ & $0.94^{a} \pm 0.17$ & $0.83^{a} \pm 0.25$ & $1.28^{a} \pm 0.26$ & $1.06^{a} \pm 0.17$ & $1.03^{a} \pm 0.19$ \\
\hline
\end{tabular}

Control $=$ non-irradiated samples, Means values within a column having different letters are significantly different $(P<0.05)$

These fruits were not accepted in the market (the score $<2.5$ ). When the storage time increased to a maximum of 12 days, scores ranged from 0.96 to 1.06 and there was insignificant difference among all samples. Color deterioration was consistent with results obtained for color value in section 3.3. Flavor value in Table 2 showed that the maximum organoleptic value for the flavor of fruits was recorded at day 0 . After that, the score was reduced during storage time and final scores ranged from 0.78 to 1.00 after 12 days. Therefore, when the storage period enhanced up to 12 days, none of the treatment retained the flavor of the star apple fruits. Higher score was observed in irradiated samples and significant difference with control sample at day 6 . However, under higher doses (>0.6kGy) of radiation, organoleptic values for flavor of fruits were decreased at day 9 and were insignificant difference with the control sample. The results obtained in the present investigation were similar to earlier reports with a gradual decrease in flavor score when increasing in storage period of guava (Basha, Shivshankar, Pande \& Shaziya, 2018), guavaPapaya fruit bar (Vennilla, 2004). Texture values significantly decreased from 4.89-5 to 1.06-1.28 after 12 days storage. The irradiation of fruits with $0.4 \mathrm{kGy}$ and $0.6 \mathrm{kGy}$ also obtained the best scores for texture, being statistically significant after 6 days (3.78 and 3.72, respectively, $P<0.05)$. The texture of fruits was not accepted by panel of judges after 12 days of storage for all treatment including control. Taste scores for irradiated sample were higher than control sample 
$(P<0.05)$ after 6 days whereas it was not significant difference after 9 days and 12 days. Irradiated samples at dose of $0.4 \mathrm{kGy}$ and $0.6 \mathrm{kGy}$ were accepted after 6 days storage with the overall acceptability range from 3.95 to 3.92 , respectively. The control sample and irradiated samples treated at dose of 0.8 to $1.0 \mathrm{kGy}$ were not accepted with the overall acceptability score lower than 2.5 (Table 2).

\section{e) Determination of uniformity ratio on the carton box containing star apple fruits}

Table 3 presented the positions of fixed dosimeters to measure absorbed doses in a carton box of products.

Table 3 Measured dose at different positions in carton box containing star apple fruit

\begin{tabular}{cc} 
Position of fixed dosimeters & Measured dose, Gy \\
\hline T1 & $416 \pm 12^{\mathrm{a}}$ \\
T2 & $409 \pm 8^{\mathrm{a}}$ \\
T3 & $417 \pm 15^{\mathrm{a}}$ \\
T4 & $400 \pm 9^{\mathrm{a}}$ \\
T5 & $440 \pm 11^{\mathrm{b}}$ \\
\hline Means values within a column having different letters are
\end{tabular}

significantly different $(P<0.05)$

The results were shown that the overall minimum absorbed dose was at the T4 (400 Gy), while overall maximum dose was at T5 (440 Gy) with corresponding calculated DUR of 1.1. It can be pointed out that the carton dimension of $49 \mathrm{~cm}(\mathrm{~L}) \times 32 \mathrm{~cm}(\mathrm{~W}) \times 12 \mathrm{~cm}(\mathrm{H})$ with gross weight of $4.0 \mathrm{~kg}$ is Table for containing star apples when applying 2-sided electron beam irradiation at VINAGAMMA Center.

Table 4 Measured doses at different positions inside and outside of the star apple fruit.

\begin{tabular}{ccc}
\hline Position of fixed dosimeters & Measured dose Inside of fruit (Gy) & Measured dose Outside of fruit (Gy) \\
\hline T1 & $422 \pm 14^{\mathrm{a}}$ & $400 \pm 13^{\mathrm{a}}$ \\
T2 & $444 \pm 18^{\mathrm{a}}$ & $400 \pm 20^{\mathrm{a}}$ \\
T3 & $422 \pm 17^{\mathrm{ab}}$ & $422 \pm 15^{\mathrm{a}}$ \\
T4 & $466 \pm 9.0^{\mathrm{b}}$ & $422 \pm 19^{\mathrm{a}}$ \\
T5 & $444 \pm 11^{\mathrm{ab}}$ & $422 \pm 14^{\mathrm{a}}$ \\
\hline
\end{tabular}

Means values within a column having different letters are significantly different $(P<0.05)$

Absorbed doses inside and outside of star apple fruits in carton box were caculated and showed in Table 4. The B3 film dosimeter was chosen due to its suiTable dose range from $1 \mathrm{~Gy}$ to $100 \mathrm{kGy}$ in EB irradiation (ASTM, 2004). The minimum dose of 422 Gy outside of the fruits at position (1) and the maximum dose of 466 Gy inside of the fruits at position (4) were measured. There results showed that the dose inside and outside the fruits of Lò Rèn star was different with DUR of 1.2. It is concluded that the dose for star apple fruits was fairly uniform at different places in the fruit. 


\section{CONCLUSION}

Our results suggested that electron beam radiations can be used as a phytosanitary measurement for star apples. In addition, the shelf life of fruits would be extended up to 6 days after treated at the same doses for phytosanitary (from 0.4 to $0.6 \mathrm{kGy}$ ). Obtained results can be applied in industrial scale for export purpose.

\section{ACKNOWLEDGEMENTS}

The work was supported by Grant CS/17/07-02 from the Vietnam Atomic Energy Institute (VINATOM). This research is a part supported by International Atomic Energy Agency (IAEA) under Research Contract $\mathrm{n}$. . 18984. The authors would like to thank the Research and Development Center for Radiation Technology (VINAGAMMA) for EB irradiation.

\section{REFERENCES}

Abu-Tarboush, H., Al-Kahtani, H., Atia, M., Abou-Arab, A., Bajaber, A., \& Mojaddidi, M. (1997). Sensory and microbial quality of chicken as affected by irradiation and postirradiation storage at 4.0. Journal of Food Protection, 60(7), 761-770. https://doi.org/10.4315/0362-028X60.7.761

Amusa, N.A., Ashaye, O.A., \& Oladapo, M.O. (2003). Biodeterioration of the African star apple (Chrysophylum albidum) in storage and the effect on its food value. African Journal of Biotechnology, 2(3), 56-59. https://doi.org/10.5897/AJB2003.000-1011

AOAC (Association of Official Analytical Chemists). (2005a). Vitamin C in juices and vitamin preparations. Official Method 967.21. In: AOAC Official Methods of Analysis, 18th ed. Association of Official Analytical Chemists, Gaithersburg, MD, USA: 45.1.14. Retrieved from https://www.scribd.com/document/176943262/AOAC-Method-Ascorbic-Ac-967-21

APHIS (Animal and Plant Health Inspection Service). (2016). Comment period opening on risk analysis to allow import of fresh star apple fruit from Vietnam into the Continental United States. Retrieved from: https://www.aphis.usda.gov/aphis/newsroom/stakeholderinfo/sa_by_date/stakeholder-announcements-2016/sa-07/star-apple-fruit-vietnam.

ASTM International. (2004). Standard practice for use of a radiochromic film dosimetry system. ISO/ ASTM 51275:2004. Standard on Dosimetry for Radiation Processing, 43-47.

Basha, S.J., Shivshankar, G., Pande, S., \& Shaziya, V. (2018). Studies on development of guava leather as a novel product. International Journal of Chemical Studies, 6(6), 1920-1929.

Chouksey, S., Singh, A., Thakur, R.S., \& Deshmukh, R. (2013). Influence of gamma irradiation and benzyl adenine on keeping quality of custard apple fruits during storage. Journal of Food Science and Technology, 50(5), 934-941. https://doi.org/10.1007/s13197-011-0412-2

Dawson, E.H., \& Harris, B. (1951). Sensory methods for measuring differences in food quality. Agriculture Information Bulletin No. 34, Bureau of human nutrition and home economics, United States Department of Agriculture Washington, D. C.

Dionísio, A.P., Gomes, R.T., \& Oetterer, M. (2009). lonizing radiation effects on food vitamins - a review. Brazilian Archives of Biology and Technology, 25(5), 1267-1278. https://doi.org/10.1590/S1516-89132009000500026

Drake, S.R., \& Neven, L.G. (1997). Quality response of "Bing" and "Rainier" sweet cherries to low dose electron beam irradiation. Journal of Food Processing and Preservation, 21, 345-351. https://doi.org/10.1111/j.1745-4549.1997.tb00788.x

Eissa, H.A., \& Zohair, A. (2006). Quality and safety of halawa modified with mushroom. Journal of the Science of Food and Agriculture, 86, 2551-2559. https://doi.org/10.1002/jsfa.2645 
Follett, P.A., Yang, M.M., Lu, K.H., \& Chen, T.W. (2007). Irradiation for postharvest control of quarantine insects. Formosan Entomology, 27, 1-15.

FruitVietnam. (2015). The star apple of Lò Rèn Vinh Kim. Retrieved from http://fruitvietnam.com/san-pham/vu-sua-lo-ren-vinh-kim.html

IFST (Institute of Food Sciences and Technology). (June 2015). Food irradiation. Retrieved from https://www.ifst.org/resources/information-statements/food-irradiation

Le, V.K. (2016). Chrysophyllum cainito. Retrieved from http://khoahocchonhanong.com.vn/csdl/Cay-vu-suaChrysophyllum-cainito.html

Moreno, M.A., Castell-Perez, Gomes, Da Silva, \& Moreira, R.G. (2006). The effects of electron beam irradiation on physical, textural and microstructural properties of "Tommy Atkins" mangoes (Mangifera indica L.). Journal of Food Science, 71(2), E80-E86. https://doi.org/10.1111/j.1365-2621.2006.tb08900.x

Moreno, M.A., Perez, M.E.C., Gomes, C., da Silva, P.F., \& Moreira, R.G. (2007).Quality of electron beam irradiation of blueberries (Vaccinium corymbosum L.) at medium dose levels (1.0-

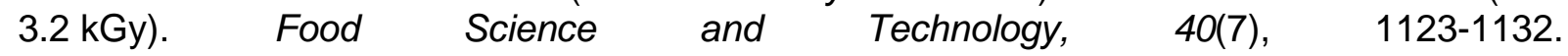
https://doi.org/10.1016/j.Iwt.2006.08.012

Pathare, P.B., Opara, U.L., Al-Said, F.A. (2012). Colour measurement and analysis in fresh and processed foods: A 453 review. Food and Bioprocess Technology, 6(1), 36-60. https://doi.org/10.1007/s11947-012-0867-9

Rabab, W.M., Khaled, M.E. (2017). Chemical quality and nutrient composition of strawberry fruits treated by y-irradiation. Journal of Radiation Research and Applied Sciences, 10(1), 80-87. https://doi.org/10.1016/j.jrras.2016.12.004

Rezaee, M., Almassi, M., Minaei, S. \& Paknejad, F. (2013). Impact of post-harvest radiation treatment timing on shelf life and quality characteristics of potatoes. Journal of Food Science and Technology, 50(2), 339-345. https://doi.org/10.1007/s13197-011-0337-9

Santos, A.M.G., Lins, S.R.O., da Silva, J.M., \& de Oliveira, S.M.A. (2015). Low doses of gamma radiation in the management of postharvest Lasiodiplodia theobromae in mangos. Brazilian Journal of Microbiology, 46(3), 841-847. https://doi.org/10.1590/S1517-838246320140363

Sau, S., Datta, P., Sarkar, T., \& Sarkar, S. (2018). Impact of low doses of gamma irradiation on offseason guava at ambient storage condition. International Journal of Current Microbiology and Applied Sciences, 7(1), 295-307. https://doi.org/10.20546/ijcmas.2018.701.032

Shaik, J.B., Godghase, S.N., Shilpa, P.S. \& Shaziya, V. (2018). Studies on development of guava leather as a novel product. International Journal of Chemical Studies, 6(6), 1920-1929.

Singh, A., Singh, D., \& Singh, R. (2006). Shelf life extension of tomatoes by gamma radiation. Radiation Science and Technology, 2(2), 17-24.

Singh, S.P., \& Pal, R.K. (2009). lonizing radiation treatment to improve postharvest life and mainta in quality of fresh guava fruit. Radiation Physics and Chemistry, 78(2), 135-140. https://doi.org/10.1016/j.radphyschem.2008.09.007

Singh, S.P., \& Pal, R.K. (2009). Ionizing radiation treatment to improve postharvest life and maintain quality of fresh guava fruit. Radiation physics and Chemistry, 78, 135-140. https://doi.org/10.1016/j.radphyschem.2008.09.007

Thomas, P. (1986). Radiation preservation of foods of plant origin. Part III. Tropical fruits: bananas, mangoes and papayas. CRC Crit. Rev. Food Science \& Nutrition, 23, 147-205. https://doi.org/10.1080/10408398609527423 
Vennilla, P. 2004. Studies on storage behavior of guava-papaya fruit bar. Beverage and Food World. 31(2), 63-66.

Wall, M.M., \& Khan, S.A. (2008). Postharvest quality of dragon fruit (Hylocereus spp.) after X-ray irradiation quarantine treatment. HortScience, 43(7), 2115-2119. https://doi.org/10.21273/HORTSCI.43.7.2115

Yahia, E.M., \& Orozco, E.G. (2011). Star apple (Chrysophyllum cainito L.) in: Postharvest biology and technology of tropical and subtropical fruits. Woodhead Publishing Series in Food Science, 392-398. https://doi.org/10.1533/9780857092618.392

Yoon, M., Jung, K., Lee, K. Y., Jeong, J. Y., Lee, J. W., \& Park, H, J. (2014). Synergistic effect of the combined treatment with gamma irradiation and sodium dichloroisocyanurate to control gray mold (Botrytis cinerea) on paprika. Radiation Physics and Chemistry, 98, 103-108. https://doi.org/10.1016/j.radphyschem.2013.12.039

Zalewska, M., Marcinkowska-Lesiak, M., \& Onopiuk, A. (2017). Physicochemical properties of white button mushrooms (Agaricus bisporus) as affected by coating. Journal of Food Processing and Preservation, e13419. https://doi.org/10.1111/jfpp.13419

Zaman, W., Paul, D., Alam, K., Ibrahim, M., \& Hassan, P. (2007). Shelf life extension of banana (musa sapientum) by gamma radiation. Journal of Bio-Science, 15, 47-53. https://doi.org/10.3329/jbs.v15i0.2202

Zhang, K., Deng, Y., Fu, H., \& Weng, Q. (2014). Effects of Co-60 gamma-irradiation and refrigerated storage on the quality of Shatang mandarin. Food Science and Human Wellness, 3(1), 9-15. https://doi.org/10.1016/j.fshw.2014.01.002 